\title{
Application of WEB Technology in Teaching Administration of \\ University
}

\author{
Min-hua Xü ${ }^{1}$ Xiao-guo Liu ${ }^{1}$ \\ ${ }^{1}$ Jilin Agricultural University, Changchun, 130118, China
}

\begin{abstract}
Keywords: Teaching administration, Computer and WEB technology, Web teaching administration system, Management mode; Advice.
\end{abstract}

\begin{abstract}
Applicationof computer and WEB technology already become the inevitable demand of teaching administration modernization of university. In this paper the author expatiates detailedly on main application of computer and WEB technology in teaching administration of university, at the same time probes into main problems existed in the process of application of computer and WEB technology in teaching administration of university in our country, finally brings forward the resolvent ways about how to strengthen the application of computer and WEB technology in teaching administration of university.
\end{abstract}

\section{Introduction}

In the daily work of teaching, there are many works is very tedious. The programming teaching plan, teaching preparation and calendar management, curriculum and publishing, and other examinations and examiners schedule, student test scores to fill and management. These efforts by the Office of Academic Affairs, the Department of each teaching leadership, academic staff, teachers work together to complete, management and implementation of the teaching work are of considerable difficulty, in the vast majority of these jobs can be done with the help of a computer, the increasingly more rely on the help of the computer to complete. Therefore, the computer and WEB technology in teaching management in universities, use of modern advanced network technology, computer technology and the corresponding database technology can achieve the daily teaching work efficient management.

\section{The important role of computer and WEB technology}

Teaching management is the various aspects of school teaching comprehensive information resources for management and control, in order to maintain the normal operation of the school teaching work, teaching educational administration of all kinds of information and data, is to analyze the teaching status, evaluation of teaching quality and teaching management decisions of important basis, but also in order to better serve the teachers and students of a public information platform, so need to be stored and comprehensive scientific management. Handle these complex and large number of data, relying on traditional way of working hard, and the application of computer technology and network technology can easily management and processing, modernization of teaching management is on the application of the computer.

At present, the colleges and universities are actively carry out higher education level of job of undergraduate course teaching evaluation, this is to improve the management level of the whole school teaching an important occasion, because as the teaching management system reform and 
adjustment of students training system, running a school are more diversified and universities' educational administration department for a variety of teaching information processing and analysis of heavy workloads, the traditional teaching management pattern has not adapted to the development of higher education management form and the needs of the work. So the opportunity to catch teaching evaluation in Jilin Agricultural university of science and technology, using computer and network technology for a new mode of college teaching management modernization and scientific, establish a highly efficient modern teaching management system. And the computer technology and network technology became the requirement of the modernization of the teaching management in colleges and universities.

\section{Computer and WEB technology in the concrete application of the teaching management in colleges and universities}

Teaching management content is very broad, involving department, staff, and to teaching quality supervision and management, student status management and daily teaching management is one of the key content. In these areas using computer and network technology management can greatly improve the work efficiency and achieve more satisfactory result of management.

Web Services Architecture is an object-oriented analysis and design logical evolution of components geared towards the architecture, design, implementation, and deployment of e-business solutions.Figure1

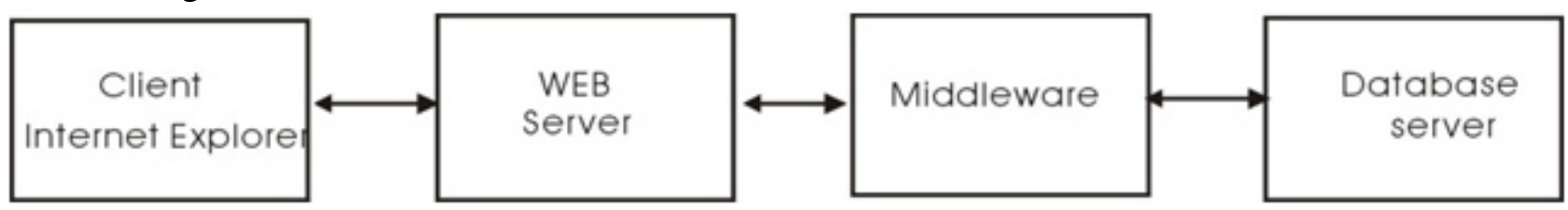

Figure1 Web Architecture

First, under the new form, currently each college in order to improve the education level and education quality as the core content of education, and the conventional teaching quality inspection are questionnaire design relevant indicators, according to the indicators by the students to grade teacher, again by the related department to make a comprehensive arrangement after feedback to the teacher. The disadvantages of this method is more, not only inefficient, but also easy to cause in the process of operation is not objective and false operation. And the use of computer network teaching quality supervision and management, can avoid the above problems, to each teacher's teaching situation provides an objective and detailed teaching supervision and feedback, to service teaching better. Students only need to their student id and password input after landing corresponding teaching quality supervision system, click options on the Internet can be successfully completed the evaluation of teachers' teaching effect, the whole process is very simple, and systems that can perform real-time statistics, collection and analysis. Teachers can timely to query its own working himself teaching quality evaluation result of each semester, including total score and ranking and the small, in order to suit the remedy to the case, the improvement of the targeted. While the teaching management staff can clearly understand the teacher's teaching effect, according to the rankings, schools can take necessary disciplinary measures accordingly. Student evaluation scores, rankings, as the teachers' working attitude, the quality of teaching evaluation, teacher evaluation and assessment is an important basis of professional titles, the implementation of the online evaluation system can avoid all sorts of shortcomings of conventional methods, at the same time can promote teachers consciously the reform of teaching methods, improve teaching quality, realize the good interaction between teaching and learning. Should go smoothly, the online teaching quality evaluation system should require all students to actively participate in, so you can use this system 
and online courses and student achievement inquiry system tied together, students must evaluate the teaching quality after can undertake online courses and scores query, in order to ensure the smooth implementation of evaluation system of the Internet.

Second, computer and network technology in the student management can also play a very important role, and student performance management is an important part of the college student management, student performance management requirements for each of the students, the nature of the course, each semester lessons, credits and grades for effective management, including performance statistics, computing, query and analysis, etc. Many college students, and each of the students in the whole process of teaching of undergraduate course to be completed dozens of general courses, so relevant data information quantity is very big and very trivial, so the traditional way of paper is difficult to handle. And use computer software for student performance management, the teacher can easily record the student's course grade, computer can automatically calculate the average, pass and excellence, etc., and can automatically will be scheduled in the position in the student achievement, the teaching management staff can also smooth the score of the students of each course, class average classification and data statistics, through the data review, system can also automatically generated students each semester and academic year total table, at the same time for students and the teaching management staff can provide a convenient query, using computer management can avoid the error of performance management, implementation management efficient and accurate.

This is just a computer and network technology in the application of several main aspects of teaching management in colleges and universities, in the rest of the computer may be used for management, can establish efficient sensitive teaching management system, improve the accuracy and efficiency in the management, make scientific and democratic decision-making argument.

\section{Computer and WEB technology in application of the main problems existing in college teaching management}

Computer and WEB technology has a broad application prospect in the teaching management in colleges and universities, but there are still many problems in the actual operation process, first of all, at the same time, the application of computer and network technology to teaching management team personnel put forward higher requirements, the general common heavy teaching in colleges and universities, the phenomenon of light management, therefore, for the construction of college teaching management team important understanding insufficiency, for a long time thought teaching management only transactional work, thus ignore the selection and development of teaching management. So the application of teaching management network system must develop relevant teaching managfunction of teaching management software to further expand, many colleges and universities are in the school year system and credit system at the present stage of transition, as the software design of a difficult problem, at the same time, the current Internet tools is not very good support the realization of online interaction, such as on-line question-answering, exams, and online discussion, etc., simple operation and management system is still not enough, the teacher must pass through the complex operation to number control system. In the modern teaching management concept, in the implementation of some of the teaching management in colleges and universities the connotation and importance of computerization, information knowledge, teaching management idea obsolete, accustomed to the traditional teaching management idea, stay on the teaching management mode and method, to experience contributed to teaching management using computerized and networked pace lags behind one of the important reasons. 


\section{Conclusion}

Computer and WEB technology in teaching management in universities still insufficient, but modern computer technology to the teaching management is not only the means and methods of change, but change the concept, structure and pattern. Computer and network technology as the core of modern information technology can contribute significantly to the level of modern teaching management, but also can greatly promote the improvement of teaching quality and management level, modern teaching management system will promote the development of adult education.

\section{Acknowlegements}

This research is supported by the 12th five-year plan education science project jilin province, China (ZC13055)

\section{References}

[1] LIU Cun-fu, Web-based teaching and research of University Fine Management Model, Inner Mongolia Coal Economy, (2014) 11-13.

[2] ZHU Jiu-yang, A Study of teaching mode of college english reading with web 2.0 A. Journal of Anhui University of Technolog, (2014) 31-32.

[3] Li Shu-jian, Design and Application of Comprehensive Teaching Management Platform based on Web Technology, China Educational Technology \& Equipment,(2011) 76-77. 